\title{
Research on multi-dimensional translation of Chinese folk songs
}

\author{
Liu Wei* \\ Nanchang Normal University, Jiangxi Nanchang, Jiangxi 330000, China.
}

\begin{abstract}
Folk songs reflect the unique spiritual value, customs and culture of a nation. The translation and transmission of folk songs is part of the effective way for Chinese culture to go abroad. The paper points out the necessity of and major tasks in folk song translation, namely the reproduction of cultural elements and rhythmic features and propose the application of multi-mode translation to bring out the best translation of folk songs.
\end{abstract}

Keywords: Chinese folk songs; Multi-mode translation; Cultural translation

Chinese folk songs have a long history and carry the cultural genes of the Chinese nation. Both literary and musical, they reflect the unique spiritual value, thinking mode and imagination of the Chinese nation, and embody the vitality and creativity of the Chinese people. As General Secretary Xi Jinping pointed out, "We need to integrate the promotion of fine traditional culture with the development of realistic culture, so as to achieve development through inheritance." In recent years, many regional folk songs have been included in the national intangible cultural heritage list. Local governments are also carrying out relevant policies and measures to actively protect and inherit folk songs. However, the protection and inheritance of folk songs should go beyond the nation. Although some representative folk songs have gone abroad and sung on world stage, the lack of translation will undoubtedly hinder the understanding and acceptance of folk songs in the foreign world, thus affecting their worldwide spread. In the context of China's implementation of the strategy of "cultural export" and "cultural power" as well as the diversified development of world culture, the reasonable translation and introduction of excellent Chinese folk songs is not only conducive to the diversified development of Chinese national culture, but also of positive significance to the demonstration of Chinese cultural spirit and the establishment of Chinese cultural confidence.Therefore, it is of great significance to promote Chinese cultural confidence and cultural "soft power".

\section{The necessity of the English translation of Folk songs}

The folk songs are literary, musical and performing, with rich and distinct themes and extensive contents. With the accelerated pace of national revival of traditional folk culture, many regional folk songs have been included in China's National Intangible Cultural Heritage List, and the protection and inheritance of traditional folk songs in various regions is being carried out in an orderly manner. As folk songs are created during work, production and in life, many of them reflect the cultural psychology and humanistic spirit of the traditional Chinese people, who are hard-working, plain, sincere, resolute, united, inclusive, pioneering and innovative. It represents the Chinese cultural and the excellent inheritance of the national intangible cultural heritage. This is very evident from the representative Xingguo mountain song "Playing mountain song over the bamboo raft" : "Hello -- ah, playing mountain song over the horizontal row, the horizontal road stone cliffs, how much stone road ah, heart and soul grid, I do not know how much rotten straw shoes" ${ }^{[1]}$. It fully embodies the tough personality and pragmatic and optimistic spirit of the Hakka people in southern Gannan, southeast China's Jiangxi province. They are brave to forge ahead despite difficulties and obstacles. Folk songs, "in the most simple language, reveal the profound truth, directly express the spirit of people, the pursuit of self, ethics, and value orientation,"[2] It is an important source of the socialist core values, a clear representation of the temperament of ordinary people, aesthetic, reiki, imagination, creativity and wisdom and understanding, and fully displays in this kind of oral literature.Therefore, the translation of Chinese classic folk songs is conducive to the exotic transmission of Chinese cultural genes.

But on the other hand, in many areas, folk songs face the threat of lack of successors and being on the verge of petrification. As an intangible cultural heritage, the protection and inheritance of folk songs are related to the country's cultural security, the harmonious development of society, and the inheritance of national culture ${ }^{[3]}$.

Secondly, from the perspective of rights discourse, the extraterritorial dissemination of folk songs is more of a discourse right. Behind this right is the game between various languages, values or ideologies of various countries and nationalities.[4] For as intangible cultural heritage protection and inheritance is the basic policy of "protection is given priority to, rescue first, reasonable use, inheritance development", and folk song "living state" translation is one of the effective ways of inheritance development, through the "live" translation, the Chinese nation unique spiritual values, ways of thinking and imagination to reveal, the cultural

Copyright (C) 2020 Liu Wei

doi: 10.18282/1-e.v9i4.1663

This is an open-access article distributed under the terms of the Creative Commons Attribution Non-Commercial License (http://creativecommons.org/licenses/by-nc/4.0/), which permits unrestricted non-commercial use, distribution, and reproduction in any medium, provided the original work is properly cited. 
identity of China to erect, a mirror image of China to avoid becoming the other culture and civilization in the world have the ability to express its own cultural diversity ${ }^{[5]}$.

\section{Translation and spread of the "living state" folk songs}

As an intangible cultural heritage, to prevent folk songs from fate of "petrification", one of the keys is to blend them with people's lives and modern culture, rather than placing them in a folk museum or performing on the stage. Similarly, The English translation of Chinese folk songs should be able to transmit them in foreign culture and language environment for acceptance, and English translation form is also one of the keys.

(1) Transfer of cultural elements

Language and culture has always been the focus of linguists and translators. The Polish semantic school hold that cross-cultural differences exist in languages. Because of differences in their values, beliefs and attitudes, different social classes and emotions, the languages of different countries have different ideas and concepts, and these concepts are embedded in their respective culture of language ${ }^{[6]}$. Susan Bassnett and Andre Lefervere hold that translation is not the transformation of the original text, but the transplant of "culture" ${ }^{[7]}$. How to effectively transplant the "folk song culture seeds" with distinct regional characteristics, shoulder the important task of spreading Chinese culture, and enrich the diversity of culture and art is an important consideration for translators.

(2) Reproduction of performing characteristics

Compared with written literature, the most outstanding characteristic of folk songs, is its liveness and performance. In folk song translation, the translator take into consideration the performer of clothes, singing scene, rhythmic features of the song, to reproduce of the folk song's singing characteristics in the translation, to make the audience understand the text, appreciate and understand the aesthetic feeling.

(3) Application of multi-mode translation

Folk song is not a single-media rap genre, but a stereoscopic multi-dimensional, literature, music and drama in various forms of art. Only relying on words, it's far from enough to reproduce the sound, tone, rhythm, beat, and connotation of folk songs. More media are needed to grasp the profound cultural connotation behind the literal meaning. Translators need to convey the rich language and cultural information of the original text a variety of media like pictures, audio, video, Internet and other forms, and multi-mode is most suitable. Multi-mode, also known as multi-symbol, refers to the phenomenon of communication through language, image, sound, action and other means and symbolic resources. Roland Barthes was the first scholar to study multimodal discourse analysis.His imagery rhetoric discusses the interactive relationship between imagery and language in expressive meaning ${ }^{[8]}$. Kress, G. made an in-depth analysis of the relationship between patterns and media as well as the expressive meaning of various patterns, and analyzed and sorted out the visual image, color grammar, layout design and the influence of different media on reading and writing ability ${ }^{[9]}$. The application of multimodal translation can break through the barriers of words and symbols, maintain the vitality of folk songs and improve foreign readers' understanding and interest in the text through various communication modes of "interlanguage and semiotics"[10]. In the translation of folk songs, colorful pictures and audio-visual discs should be used comprehensively to present the content and cultural context of folk songs and reproduce their original appearance, so that readers can feel their unique artistic charm and cultural appeal.

\section{Conclusion}

With Chinese culture drawing more and more attentions for across the world, though still in its infancy, the study of folk songs translation is bound to attract more interest. It's thus reasonable to believe that with the advances in multi-mode translation, the study of folk songs translation will yield more results and contribute to the dissemination of Chinese culture.

\section{Reference}

[1] Zhang Hong. Dilemma: Protection or Innovation of Hakka Folk Songs in Southern Gannan [J]. Jiangxi Social Science, 2006 (7).

[2] Hou Yangjun. Human music is easy, but natural music is hard to learn -- Reflections on Protecting and Inheriting Hakka Folk Songs and Oral Literature, Folk Culture Forum, 2013 (3).

[3]Fan Zouyin. "Abing Music" -- Art Treasures in intangible Cultural Heritage [J]. People’s Music, 2008 (9) : 64-66.

[4] Wang Rongpei, Jin Xu, WANG Hong, DU Zhengming. Wu Ge Jing [M]. Suzhou: Soochow University Press, 2003:2-3

[5] Zhou Caiyu. Research on discourse Construction and Cultural Communication of Translated Intangible Cultural Heritage [J]. Sichuan Drama, 2016 (12) : 92

[6] Liu Bing, Zhong Shouman. A Multidimensional Study of National Culture and Language [J]. Foreign Language Teaching, 2014 (7).17-18

[7] Bassnett, Susan \& Lefervere, Andre. Constructing Cultures - Essays on Literary Translation [M]. Shanghai: Shanghai ForeignLanguage Education Press, 2001:57-108

[8] Barthes, R. The Rhetoric of The Image [A]. London, UK: Fontana 1977.

[9] Kress, G.\&Theo van Leeuwen, T.Modtimodal Discourse: The Modes and Media of Contemporary Communication [M]. London: Arnold, 2001.

[10] the inheritance and development about the implementation of Chinese excellent traditional culture the opinions of the project "a reporter asked [EB/OL] http://politics.people.com.cn/n1/2017/0207/c1001-29062488.html. 08:28 feb 07, 2017 source:Xinhua News Agency Project Fund: The study is supported by "11531" Research Project fund of Nanchang Normal University. 